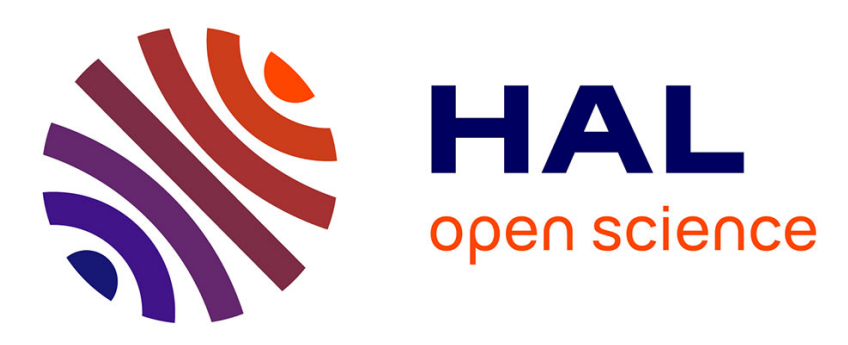

\title{
Long-term infliximab therapy is needed for sustained steroid-free remission in patients with ulcerative colitis
}

Florence Le Roy, Laurent Siproudhis, Jean-François Bretagne, Guillaume Bouguen

\section{- To cite this version:}

Florence Le Roy, Laurent Siproudhis, Jean-François Bretagne, Guillaume Bouguen. Long-term infliximab therapy is needed for sustained steroid-free remission in patients with ulcerative colitis. Digestive and Liver Disease, 2016, 48 (2), pp.208-209. 10.1016/j.dld.2015.10.020 . hal-01237104

HAL Id: hal-01237104

https://hal-univ-rennes1.archives-ouvertes.fr/hal-01237104

Submitted on 27 Jan 2016

HAL is a multi-disciplinary open access archive for the deposit and dissemination of scientific research documents, whether they are published or not. The documents may come from teaching and research institutions in France or abroad, or from public or private research centers.
L'archive ouverte pluridisciplinaire HAL, est destinée au dépôt et à la diffusion de documents scientifiques de niveau recherche, publiés ou non, émanant des établissements d'enseignement et de recherche français ou étrangers, des laboratoires publics ou privés. 
Letter to the Editor

Long-term infliximab therapy is needed for sustained steroid-free remission in patients with ulcerative colitis

Florence Le Roy ${ }^{1}, M D$, Laurent Siproudhis ${ }^{1,2}$, MD-PhD, Jean-François Bretagne ${ }^{1}$, MD-

PhD, Guillaume Bouguen ${ }^{1,2}, \mathrm{MD}-\mathrm{PhD}$

${ }^{1}$ Gastorenterology Unit, CHU Pontchaillou, University of Rennes 1, France

${ }^{2}$ INSERM U991, University of Rennes 1, France

${ }^{3}$ Functional Digestive Disorders Unit, CHU Pontchaillou, University of Rennes 1, France

Correspondence to:

Guillaume Bouguen

Service des Maladies de l'Appareil Digestif

2 rue Henri le Guillou

35033 Rennes Cedex, FRANCE

Telephone (0033)-2-99-28-43-17 / Fax (0033)-2-99-28-41-89

Email: guillaume.bouguen@free.fr

word count (excluding abstract, references, tables, figures) : 577

This work did not receive any financial support.

Conflict of interest:

G.B. received lecture fees from Abbvie, Ferring and MSD Pharma 
LS received lecture fees and grants from MSD Pharma

J-FB received lecture fees from Abbvie

FLR, none declared 
Dear Editor,

Data on the long-term efficacy of infliximab (IFX) in ulcerative colitis (UC) are scarce and there is limited evidence especially on sustained steroid-free remission and outcomes after IFX withdrawal. The ability of IFX to modify the course of the disease in the long-term, such as decreasing the need for surgery, remains questionable. ${ }^{1}$ After 10 to 24 months of follow-up, retrospective studies report heterogeneous remission rates for UC between $17 \%$ and $90 \% .^{2-4}$ This wide range of remission may be due to the duration of IFX exposure, therefore affecting outcomes after IFX discontinuation. In small cohorts of 4 to 51 patients in remission, the rate of relapse following IFX discontinuation ranged from $0 \%$ to $59 \%$ after 6.5 months to 4.5 years of follow-up. ${ }^{2,5}$ This rate of relapse leads to difficult decision-making regarding maintenance therapy with IFX.

We reviewed the medical charts of 100 patients treated with IFX for UC in a single gastroenterology unit between 2005 and 2012. Clinical remission was defined as a partial Mayo score of 2 points or lower, without bleeding; response, by a decrease of 2 points; and relapse, by an increase of 2 points. Survival curves were estimated by the Kaplan-Meier method and compared using the log rank statistic. A Cox proportional hazards regression model was used to assess independent predictors of each event. Seventeen of the 100 patients were treated for acute, severe UC (refractory to intravenous steroids); 83, for steroid dependency or secondary to immunosuppressive therapy failure. In total, $52 \%$ of patients had concomitant immunosuppressive therapy at baseline. 
After a median duration follow-up of 55.1 months (IQR, 35.2-74.4), 35\% of patients underwent surgery (median time from IFX initiation: 9.4 months). CRP $>6 \mathrm{mg} / \mathrm{L}$ at week 6 was the only independent factor associated with colectomy $(\mathrm{HR}=3.43,95 \% \mathrm{Cl}, 1.17-$ 10.9; $p=0.023)$. Sixty-four patients $(64 \%)$ reached clinical remission after a median time of 20 weeks following IFX initiation (IQR, 6.5-47), and 28/64 (44\%) relapsed during follow-up. The cumulative probabilities of sustained clinical remission at 1,3 and 5 years were 74, 52 and 39\%, respectively. Based on standard clinical and biological parameters at IFX initiation and on the short-term outcomes, the independent factors associated with sustained clinical remission were: duration of IFX therapy $>1$ year $(\mathrm{HR}=2.61,95 \% \mathrm{Cl}, 1.05-7.01 ; p=0.03)$, leukocyte count $<10,000 / \mathrm{mm}^{3}(\mathrm{HR}=2.18,95 \% \mathrm{Cl}$, 1.02-4.77; $p=0.04)$ and platelet count $<400,000 / \mathrm{mm}^{3}(\mathrm{HR}=2.77,95 \% \mathrm{Cl}, 1.18-6.46$; $p=0.02)$ at IFX initiation. Severe acute colitis at baseline did not influence long-term outcomes.

Finally, IFX was discontinued in $38 / 64$ patients because of steroid-free clinical remission. After a median follow-up of 54 months (IQR, 25.4-64.5) following IFX withdrawal, 4/38 patients underwent colectomy (10\%), 24 relapsed (63.2\%), and 14 remained in clinical remission (36.8\%). The cumulative probabilities of relapse after IFX discontinuation were $24 \%, 61 \%$ and $81 \%$ at 1,3 and 5 years, respectively (Figure 1). Based on univariate and multivariate analyses, age $<21$ years at diagnosis $(H R=12$, $95 \% \mathrm{Cl}, 2.77-58.24 ; \mathrm{p}=0.001)$ and a platelet count $>400,000 / \mathrm{mm}^{3}$ at IFX withdrawal $(\mathrm{HR}=6.68,95 \% \mathrm{Cl} 1.55-30.82 ; \mathrm{p}=0.011)$ were associated with relapse. Continuous use of thiopurines following IFX withdrawal did not modify patient outcome and was not 
associated with sustained clinical remission $(p=0.29)$ or relapse $(p=0.61)$ or with disease extent and disease severity at baseline.

In conclusion, after a 5-year follow-up IFX discontinuation in UC patients led to a high rate of relapse and was inversely associated with sustained remission. In our series, one-third of patients underwent colectomy, one-third relapsed and only one-third experienced a sustained clinical remission. These results support the use of long-term IFX maintenance therapy in these patients. 


\section{Figure Legend}

Figure 1: Cumulative probabilities of relapse after infliximab discontinuation in ulcerative colitis patients in steroid-free clinical remission. 


\section{REFERENCES}

1. Oussalah A, Evesque L, Laharie D, et al. A multicenter experience with infliximab for ulcerative colitis: outcomes and predictors of response, optimization, colectomy, and hospitalization. Am J Gastroenterol. 2010;105:2617-25.

2. Arias MT, Vande Casteele N, Vermeire S, et al. A panel to predict long-term outcome of infliximab therapy for patients with ulcerative colitis. Clin Gastroenterol Hepatol. 2015;13:531-8.

3. Gies N, Kroeker KI, Wong K, et al. Treatment of ulcerative colitis with adalimumab or infliximab: long-term follow-up of a single-centre cohort. Aliment Pharmacol Ther 2010;32:522-8.

4. Lee KM, Jeen YT, Cho JY, et al. Efficacy, safety, and predictors of response to infliximab therapy for ulcerative colitis: a Korean multicenter retrospective study. J Gastroenterol Hepatol 2013;28:1829-33.

5. Steenholdt C, Molazahi A, Ainsworth MA, et al. Outcome after discontinuation of infliximab in patients with inflammatory bowel disease in clinical remission: an observational Danish single center study. Scand J Gastroenterol 2012;47:51827. 


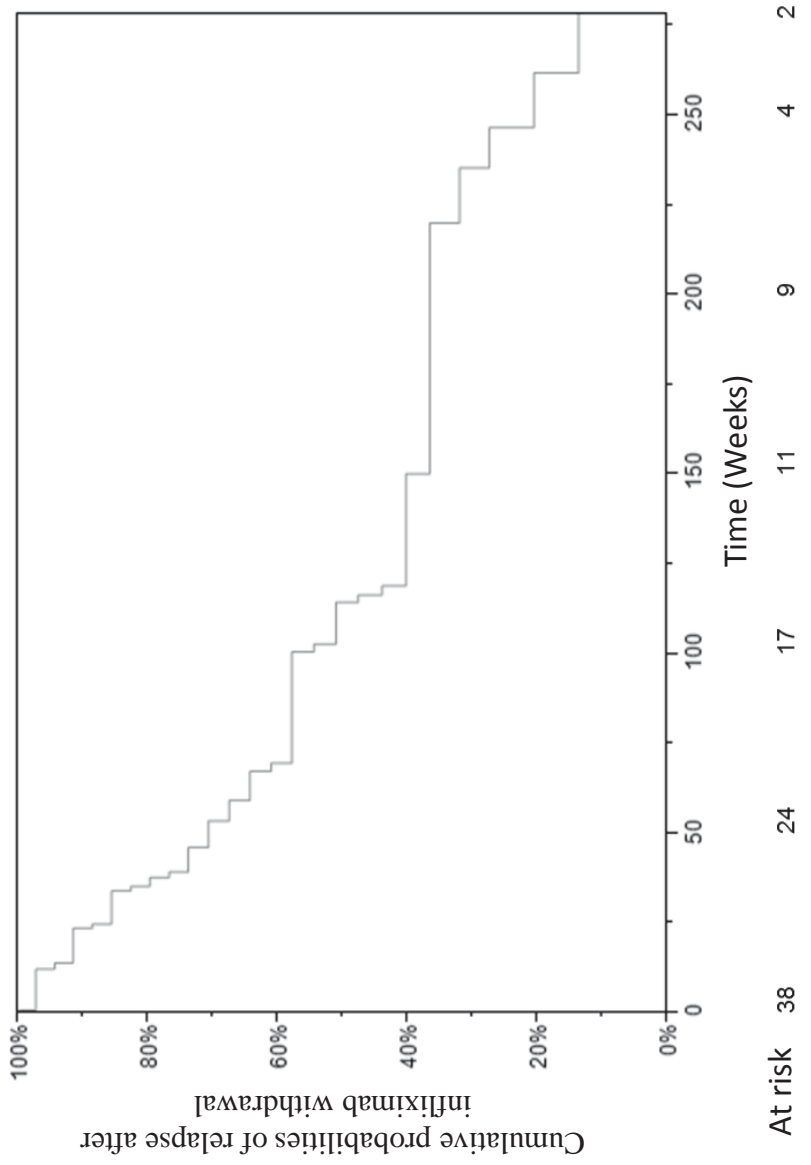

F 